\title{
Bilateral Plexiform Neurofibroma of the Sciatic Nerve Associated with Neurofibromatosis Type 1: A Rare Case
}

Fekhaoui Mohammed Reda M.D ${ }^{1 *}$, Ghannam Abdelaziz M.D ${ }^{1}$, Boufettal Moncef Ph.D ${ }^{1,2}$, Bassir Rida-Allah Ph.D ${ }^{1,2}$, Kharmaz Mohammed Ph.D ${ }^{1}$, Lamarni Moulay Omar Ph.D ${ }^{1}$, Berrada Mohammed Saleh Ph.D ${ }^{1}$

${ }^{1}$ Department of Trauma and Orthopedic Surgery, Ibn Sina University Hospital, Faculty of Medicine, Mohamed V University of Rabat, Rabat, Morocco ${ }^{2}$ Department of Anatomy, Faculty of Medicine, Mohamed V University of Rabat, Rabat, Morocco

DOI: $10.36347 /$ sjams.2020.v08i08.015

| Received: 13.08.2020 | Accepted: 20.08.2020 | Published: 22.08.2020

*Corresponding author: Fekhaoui Mohammed Reda

Abstract

Neurofibromatosis type 1 (NF1) or von Recklinghausen's disease is a phakomatosis transmitted by autosomal dominant inheritance. It is diagnosed when some criteria are present in the same individual. Patients with NF1 tend to develop neurofibromas which is a are benign tumor of peripheral nerve sheath cells. We describe the rare case of a 32year-old man with NF1 and a bilateral plexiform neurofibroma of the sciatic nerve. Given the high surgical risk, the patient was maintained under clinical and radiological surveillance. The evolution is unpredictable and current treatment options are limited to surgical resection. Radiation is not used because it could actually promote malignant transformation and it's known that neurofibroma is non-responsive to chemotherapy. Angiotensin-converting enzyme inhibitors have been proposed as a novel treatment of neurofibromas and recently the administration of interferon- $\alpha$ gave good results in unresectable, progressive and symptomatic lesions.

Keywords: Neurofibromatosis, Plexiform, Neurofibroma, sciatic.

Copyright @ 2020: This is an open-access article distributed under the terms of the Creative Commons Attribution license which permits unrestricted use, distribution, and reproduction in any medium for non-commercial use (NonCommercial, or CC-BY-NC) provided the original author and source are credited.

\section{INTRODUCTION}

Neurofibromatosis type 1 (NF1) or von Recklinghausen's disease is one of the most common genetic diseases, transmitted by autosomal dominant inheritance and affecting $1 / 3000$ to $1 / 4000$ individuals. The diagnosis is usually made easily, based on physical examination [1]. There are two peripheral nerve sheath tumors found in patients with NF1: neurofibroma, a benign tumor, and malignant peripheral nerve sheath tumor (MPNST). Plexiform neurofibroma and localized intraneural neurofibroma are significant precursors of MPNST [2]. We describe the rare case of a 32-year-old man with neurofibromatosis type 1 and a bilateral plexiform neurofibroma of the sciatic nerve.

\section{Case Presentation}

A 32-year-old man was referred for a 2-year history of bilateral and diffuse thigh pain. He was monitored since childhood by a physician for NF1. Physical examination found a bilateral palpable mass of the thigh. Neurological examination was normal. Clinical manifestations of NF1 were founded: multiple café-au-lait spots in the trunk, abdomen and lower limb (Figure 1). Routine laboratory tests were normal and standard radiographic study did not show any bone abnormality. Magnetic resonance imaging was performed and found two masses, well-delimited, located on the sciatic nerve route, measuring $7.6 \times 4.0 \times$ $3.2 \mathrm{~cm}$ (right mass) and $3.4 \times 3 \times 2 \mathrm{~cm}$ (left mass) associated with multiple nodular stringshaped lesions distributed along the nerve roots. These lesions were hyperintense in $\mathrm{T} 2$ with hypointense central focus (target sign) suggesting the diagnosis of plexiform neurofibromas of the sciatic nerve (Figure 2). A biopsy was performed and confirmed the diagnosis. Given the high surgical risk and since the lesion doesn't compromise functionality or hasn't undergone malignant transformation, the patient was maintained under clinical and radiological surveillance every six months for three years with medical pain control. After 3 years, these lesions remain stable. 


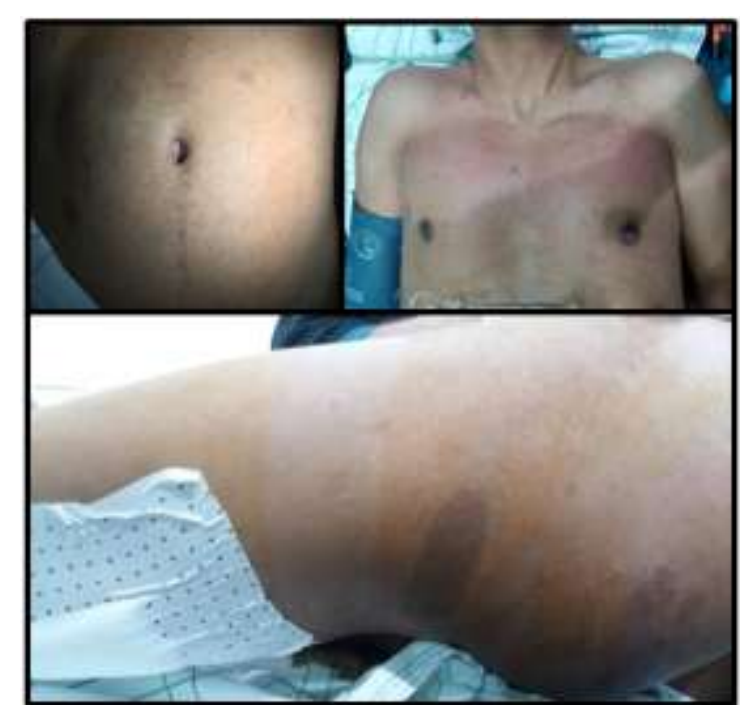

Fig-1: Clinical image showing "café-au-lait" macules in the trunk, abdomen and lower limb

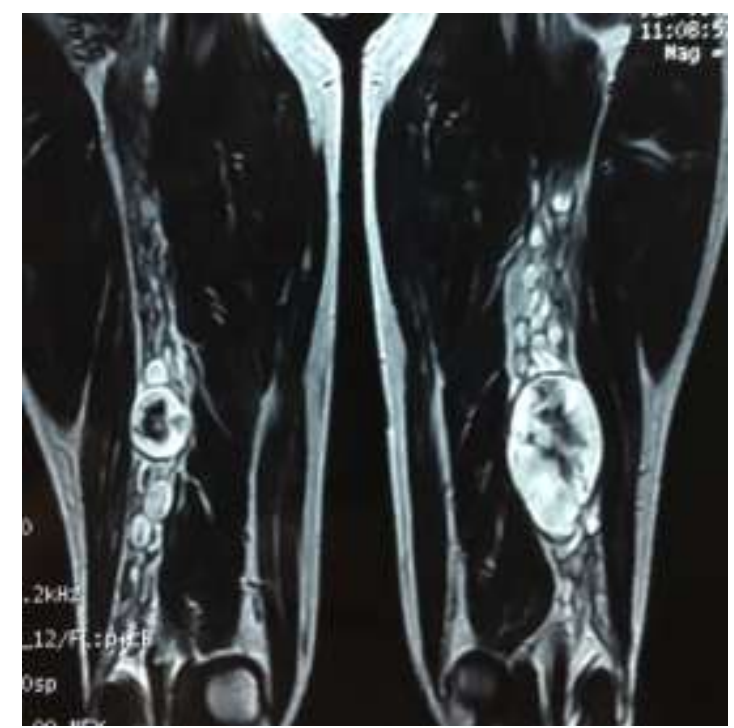

Fig-2: Magnetic resonance imaging showing bilateral plexiform neurofibromas of the sciatic nerve

\section{DiSCUSSION}

Neurofibromatosis type 1 was first described in 1793 then better documented and understood in 1882 by von Recklinghausen [3]. It's one of the most common phakomatosis, transmitted by autosomal dominant inheritance [4]. Von Recklinghausen's disease is diagnosed when at least two of these 7 main criteria are present in the same individual $[1,5,6]$ :

- First-degree relative afflicted.

- At least 6 café-au-lait macules.

- Freckling in the axillary or inguinal region (Crowe sign).

- At least 2 neurofibromas of any type or at least 1 plexiform neurofibroma.

- Optic nerve glioma.

- At least 2 Lisch nodules

- A characteristic bone lesion: pseudoarthrosis, sphenoid wing dysplasia, thinning of long bone cortex
Patients with NF1 tend to develop neurofibromas, whereas patients with NF2 harbor schwannomas. Common tumors of the sciatic nerve are schwannomas and neurofibromas [7-9]. Neurofibromas are benign tumors of peripheral nerve sheath cells (WHO grade 1) and can be divided into 2 groups: the diffuse infiltrative and the intraneural. The latter typically affects larger nerves and can be either solitary or fusiform tumors or, rarely plexiform and pathognomonic of NF1 [10, 11]. Plexiform neurofibromas are slow-growing tumors and may be unilateral or bilateral. The symptomatology may vary according to the localization [12] and a palpable mass is usually the only presenting symptom of peripheral nerve tumors [13]. MRI is the most useful imaging modality that has increased the detection of peripheral nerve abnormalities. Plexiform neurofibroma typically show hypointense $\mathrm{T} 1$ and hyperintense $\mathrm{T} 2$ signal with the characteristic target sign (central hypointense region) $[5,11]$. The evolution is unpredictable and $10 \%$ of plexiform neurofibromas undergo transformation into a malignant peripheral nerve sheath tumor $[1,14,15]$. Current treatment options are limited to surgical resection with a recurrence in $20 \%$ of cases [16]. It's usually difficult or even not possible because of the extensive and the infiltrating nature of these tumors but it's performed when the lesion is severely disfiguring, compromises functionality or has undergone malignant transformation $[17,18]$. Radiation is not used because it could actually promote malignant transformation [19] and it's known that neurofibroma is non-responsive to chemotherapy [20]. Angiotensin-converting enzyme (ACE) inhibitors have been proposed as a novel treatment of neurofibromas [21] and recently the administration of interferon- $\alpha$ gave good results in unresectable, progressive and symptomatic lesions [22].

\section{CONCLUSION}

Plexiform neurofibromas are rare benign tumors pathognomonic of neurofibromatosis type 1, with an unpredictable evolution and a risk of malignant transformation. The diagnosis of these lesions is frequently delayed. In this case, surgical intervention was not possible and we chose to undergo clinical follow-up every 6 months for 3 years. Angiotensin converting enzyme inhibitors and interferon- $\alpha$ need to be discussed as a possible therapy options of plexiform neurofibromas.

\section{Conflicts of Interest}

The authors declare that they have no conflicts of interest.

\section{Funding Statement}

All authors disclose that this manuscript didn't receive no specific grant from any funding agency. 


\section{ACKNOWLEDGMENTS}

Fekhaoui MR and Ghannam A make substantial contributions to acquisition of data, conception, design, analysis and interpretation of data. Bassir RA, Boufettal M, Kharmaz M, Lamrani MO and Berrada MS participate in revising it critically for important intellectual content and give final approval of the version to be submitted

\section{REFERENCES}

1. Pinson S, Neurofibromatosis type I. Orphanet encyclopedia; 2002.

2. Woodruff JM. Pathology of tumors of the peripheral nerve sheath in type 1 neurofibromatosis. Am J Med Genet. 1999 Mar 26; 89(1):23-30.

3. Riccardi VC. Medical progress: von Recklinghausen neurofibromatosis. $\mathrm{N}$ engl J med 1981; $305: 1617-27$

4. Geller M, Bonalumi AF. Neurofibromatose: clínica, genética e terapêutica. $1^{\mathrm{a}}$ ed. Rio de Janeiro: Guanabara Koogan; 2004

5. Pinson S, Wolkenstein P. La neurofibromatose 1 (NF1) ou maladie de von Recklinghausen. Rev Med Int. 2005; 26(3): 196-215.

6. Abouchadi A, Nassih M, Rzin A. Le neurofibrome plexiforme orbito-temporal : à propos de 6 cas. Rev Stomatol Chir Maxillofac. 2005; 106(5): 272-5.

7. Jacques C, Dietmann J. L Imagerie de la neurofibromatose de type 1 J. Neuroradiol., 2005; 32(3): 180-197

8. Aoki S, Barkovich AJ, Nishimura K, Kjos BO, Machida T, Cogen P, and Edwards M, Norman D: Neu- rofibromatosis types 1 and 2: cranial MR findings. Radiology. 1989; 172: 527-534, 1989

9. Woodruff JM. The pathology and treatment of peripheral nerve tumors and tumor-like conditions. CA Cancer J Clin. 1993; 43: 290-308

10. Jacqueline L. Anderson, David H. Gutmann, in Handbook of Clinical Neurology; 2015

11. Beatriz M, Lopes S, Bernd W. Scheithauer, in Brain Tumors (Third Edition); 2012

12. Lange F, Herlin C, Frison L, Bessis D, RouleauDubois C, Bigorre M, Captier G. Prise en charge du neurofibrome plexiforme isolé de l'enfant: à propos de quatre observations. InAnnales de Chirurgie
Plastique Esthétique 2013 Dec 1 (Vol. 58, No. 6, pp. 694-699). Elsevier Masson.

13. Kehoe NJ, Reid RP, Semple JC. Solitary benign peripheral-nerve tumours. Review of 32 years' experience. J Bone Joint Surg Br. 1995; 77: 497 500

14. Ariel IM. Tumors of the peripheral nervous system. CA Cancer J Clin. 1983;33(5):282-99,

15. Das Gupta TK, Brasfield RD. Solitary malignant schwannoma. Ann Surg. 1970;171(3):419-28

16. Mautner VF, Friedrich RE, von Deimling A, Hagel C, Korf B, Knöfel MT, Wenzel R, Fünsterer C. Malignant peripheral nerve sheath tumours in neurofibromatosis type 1: MRI supports the diagnosis of malignant plexiform neurofibroma. Neuroradiology. 2003 Sep 1;45(9):618-25.

17. Needle MN, Cnaan A, Dattilo J, Chatten J, Phillips PC, Shochat S, Sutton LN, Vaughan SN, Zackai EH, Zhao H, Molloy PT. Prognostic signs in the surgical management of plexiform neurofibroma: the Children's Hospital of Philadelphia experience, 1974-1994. The Journal of pediatrics. 1997 Nov $1 ; 131(5): 678-82$.

18. Beggs I, Gilmour HM, Davie RM. Diffuse neurofibroma of the ankle. Clinical radiology. 1998 Oct 1;53(10):755-9.

19. Ross AL, Panthaki Z, Levi AD. Surgical management of a giant plexiform neurofibroma of the lower extremity. World neurosurgery. 2011 May 1;75(5-6):754-7.

20. Isler MH, Fogaça MF, Mankin HJ. Radiation induced malignant schwannoma arising in a neurofibroma. Clinical Orthopaedics and Related Research®. 1996 Apr 1;325:251-5.

21. Lantieri L, Meningaud JP, Grimbert P, Bellivier F, Lefaucheur JP, Ortonne N, Benjoar MD, Lang P, Wolkenstein P. Repair of the lower and middle parts of the face by composite tissue allotransplantation in a patient with massive plexiform neurofibroma: a 1-year follow-up study. The Lancet. 2008 Aug 23;372(9639):639-45.

22. Namazi H. ACE inhibitors: A novel treatment for neurofibroma. Ann Surg Oncol. 2008;15:1538-9

23. Citak EC, Oguz A, Karadeniz C, Okur A, Memis L, Boyunaga O. Management of plexiform neurofibroma with interferon alpha. Pediatric hematology and oncology. 2008 Jan 1;25(7):673-8. 